\title{
Amphipathic Segment of the Nicotinic Receptor Alpha Subunit Contains Epitopes Recognized by T Lymphocytes in Myasthenia Gravis
}

Reinhard Hohlfeld, ${ }^{\star}$ Klaus V. Toyka, ${ }^{\star}$ Lucinda L. Miner, ${ }^{\ddagger}$ Susan L. Walgrave, ${ }^{\ddagger}$ and Bianca M. Conti-Tronconi ${ }^{\star}$

*Department of Neurology, University of Duesseldorf, Duesseldorf, Federal Republic of Germany; and ${ }^{\ddagger}$ Department

of Biochemistry, University of Minnesota, St. Paul, Minnesota 55108

\begin{abstract}
Autoimmune helper $T$ lymphocytes were selected from the blood of two myasthenic patients of different HLA-DR type, using acetylcholine receptor (AChR) from Torpedo californica. These polyclonal $\mathbf{T}$ cell lines were tested for reactivity with three synthetic peptides corresponding to the $\mathrm{NH}_{2}$-terminal region of the human AChR alpha subunit. This segment is a good candidate for $T$ cell epitopes since it has a propensity to form an amphipathic alpha helix. The peptides elicited 10-30\% of the response induced by native Torpedo AChR. Different peptides were recognized by the autoreactive $T$ cells of the two patients. These results suggest that the $\mathrm{NH}_{2}$-terminal region of the AChR alpha chain contains T cell-stimulating epitopes, and that the $T$ cell autoimmune response in myasthenia gravis, like the $B$ cell response, is heterogeneous.
\end{abstract}

\section{Introduction}

Myasthenia gravis (MG) ${ }^{1}$ is characterized by failure of the neuromuscular transmission. This is mainly caused by a loss of functional acetylcholine receptors (AChRs), induced by binding of anti-AChR antibodies (reviewed in reference 1). The $\mathrm{AChR}$ is a complex transmembrane protein formed by four homologous subunits in a stoichiometry $\alpha_{2} \beta \gamma \delta(2,3)$. The amino acid sequence of $\mathrm{AChR}$ subunits from different tissues and animals is known. Their structure is highly conserved, and subunits of corresponding molecular weight from different species are very similar. The alpha subunit dominates the anti-AChR antibody response in MG. A substantial fraction of antibodies bind to a discrete area of the alpha subunit, called the "main immunogenic region" (4). However, the B cell response is clearly polyclonal, and even the anti-main immunogenic region antibodies do not have a predominant idiotype (5). These observations have dampened the initial optimism about the therapeutic potential of anti-idiotypic antibodies. Since the anti-AChR antibody synthesis is regulated by AChR-specific $T$ helper cells (6-8), these $T$ cells are another possible target for immunotherapeutic intervention (9). It is therefore important to understand how the autoimmune B

Dr. Hohlfeld's present address is Neuromuscular Research Laboratory, Mayo Clinic, Rochester, MN 55905.

Received for publication 9 July 1987 and in revised form 24 September 1987.

1. Abbreviations used in this paper: $\mathrm{AChR}$, acetylcholine receptor; MG, myasthenia gravis.

J. Clin. Invest.

(C) The American Society for Clinical Investigation, Inc.

$0021-9738 / 88 / 03 / 0657 / 04 \$ 2.00$

Volume 81, March 1988, 657-660 cells and the corresponding helper $\mathrm{T}$ cells recognize the same complex antigen, how their recognition is influenced by the class II histocompatibility molecules expressed by the patient, and how these two cell compartments interact with each other.

We have recently found that the majority of the epitopes recognized by AChR-specific $T$ helper cells are present on the denatured alpha subunit (8). The present study is a first step in an effort to identify the segments of the alpha subunit that form epitopes recognized by the helper $T$ cells, and to elucidate how diverse the $\mathrm{T}$ cell response is in different patients.

\section{Methods}

Patients. AChR-reactive $\mathrm{T}$ cell lines were isolated from two patients who had generalized MG according to clinical, pharmacological, and electrophysiological criteria. The serum concentration of anti-AChR antibodies (measured with a modified radioprecipitation assay (10) and expressed as nanomoles alpha-bungarotoxin-binding sites per liter of serum) was 2.0 in patient 1 (40 yr; male), and $1,690.0$ in patient 2 (20 yr; female). The patients had not been taking immunosuppressive medications for at least 3 mo before the time when the $T$ cell cultures were started (see below). HLA types, determined with standard microlymphotoxicity techniques, were $A w 24, A 28 / B w 35, B w 51 / C w 3,-/$ $D R 1, D R 4$ (patient 1) and $A 1, A 31 / B 8,-/ C w 7,-/ D R 3, D R w 8$ (patient 2).

Isolation of $A C h R$-reactive $T$ cell lines. AChR-reactive $\mathrm{T}$ cell lines were obtained from the peripheral blood as described previously (6-8). Briefly, PBMC were initially cultured in bulk cultures in the presence of $5 \mu \mathrm{g} / \mathrm{ml}$ Torpedo AChR. After 4-6 d the reactive lymphoblasts were separated from the small, resting lymphocytes by centrifugation on Percoll density gradients (Pharmacia Fine Chemicals, Div. of Pharmacia, Uppsala, Sweden) and were propagated further by repeated stimulation cycles with IL-2 (Lymphocult-T LF, Biotest, Frankfurt, FRG) followed by $5 \mu \mathrm{g} / \mathrm{ml}$ Torpedo AChR plus mitomycin C-treated autologous or HLA-matched PBMC as antigen-presenting cells. These polyclonal CD3,CD4-positive helper $\mathrm{T}$ cell populations were analyzed for antigen fine specificity as soon as a satisfactory enrichment in AChR reactivity was achieved, i.e., after $\sim 4$ wk of culture (see Results). The $T$ cells from patient 2 were isolated early in 1987 and were used freshly for fine specificity analysis (see below). The $T$ cells from patient 1 were isolated in 1983, before the patient had a clinical relapse necessitating the institution of immunosuppressive therapy. After continuous propagation in culture until 1984, these cells were frozen in RPMI 1640 (Gibco Europe, Gibco Div., Karlsruhe, FRG), containing 10\% DMSO and 20\% FCS (Gibco Europe), and were maintained in liquid nitrogen until use in 1987.

Peptide synthesis and characterization. Three peptides, each between 14 and 16 residues long and having 4-8 overlapping residues, were synthesized by manual parallel synthesis (11). The minimum amount obtained for each peptide was $5 \mathrm{mg}$. These peptides correspond to the amino-terminal 34 residues of the human AChR alpha subunit sequence (Fig. 1). Computer analysis of the total alpha subunit sequence for propensity to form alpha amphipathic helices $(12,13)$ had indicated that this segment has the highest degree of periodic amphipathicity both in the human and Torpedo alpha subunit (unpublished results; obtained and kindly made available to us by Drs. James Cornette, Hannah Margalit, Charles DeLisi, and Jay A. Berzofsky). The 


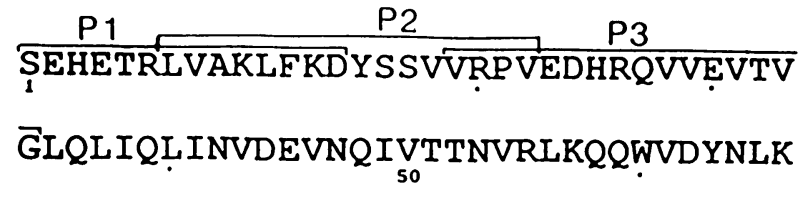

WNPḌDYGGVKKIHỊPSEKIWRPDḶVLYNNADGD

FAIVKFTKVLLQYTGHITWTPPAIEKSYCEIIV

THFPFDEQNCSMKLGTWTYPGSVVAINPESDQP

DLSNFMESGEWVIKẸSRGKHSVTỴSCCPDTPY

LDITYHEVMQRIPLYEIVNVI IPCLLESELTGLL

VEYLPTDSGEKMTLSISV_LISLTVELLVIVELI

PSTSSẠVIIGKYMLFTMVEVIASIIITVIVIN

$\underset{7}{T H}{ }_{300}$ RSP STHVMPNWWVRKVF IDT TPPNIMFFSTMK

RPSREKQDKKGIETEDIDISDISGKPGPPPMGFH

\section{SPLIKHPEVKSAIEGIKYYIAETMKSDQESNNAA}

\section{AEWKYVAMVMDHIḶLGVEMLVCI I GTLAVFAGR}

\section{LIELNQQG}

Figure 1. Amino acid sequence of the human AChR alpha subunit. The three overlapping $\mathrm{NH}_{2}$-terminal peptides used for $\mathrm{T}$ cell stimulation are designated P1-P3. M1-M4 denote four of the presumably five transmembrane regions (see reference 2 for review). The carboxy-terminal intracellular sequence is at the bottom.

purity of the synthetic peptides ranged between 65 and $85 \%$, as assessed by reverse phase HPLC using a C18 column (Ultrasphere ODS), and a gradient of acetonitrile in $0.1 \%$ trifluoroacetic acid in water. The sequence of the peptides was examined by amino acid analysis, using phenylthiocarbamyl derivatives of the amino acids released by acid hydrolysis (14).

Proliferation assay (unselected PBMC). PBMC were isolated by centrifugation over Ficoll-Hypaque gradients (Pharmacia Fine Chemicals), washed in Hepes-buffered RPMI 1640 (Gibco Europe), and cultured in triplicate in round bottom microtiter plates (Nunc, Roskilde, Denmark) at a concentration of $2 \times 10^{5}$ cells in $0.2 \mathrm{ml}$ of culture medium composed of RPMI 1640 (Gibco Europe) supplemented with $10 \%$ heat-inactivated $\left(56^{\circ} \mathrm{C}, 30 \mathrm{~min}\right)$ human $\mathrm{AB}$ serum (Gibco Europe), $2 \mathrm{mM} \mathrm{L}$-glutamine, $100 \mathrm{U} / \mathrm{ml}$ penicillin, and $50 \mu \mathrm{g} / \mathrm{ml}$ streptomycin. The following antigens (or lectins) were used: purified protein derivative (tuberculin) (Behring, Marburg, FRG; $1 \mu \mathrm{g} / \mathrm{ml}$ ), tetanus toxoid (Behring; $1 \mu \mathrm{g} / \mathrm{ml}$ ), solubilized Torpedo AChR (8) $(5 \mu \mathrm{g} / \mathrm{ml})$, synthetic peptides of the human AChR alpha subunit (see above; 1 $\mu \mathrm{g} / \mathrm{ml}$ ), and PHA (Wellcome Reagent Ltd., Beckenham, England; 1 $\mu \mathrm{g} / \mathrm{ml})$. After $72 \mathrm{~h}$ the cultures were pulsed with $\left[{ }^{3} \mathrm{H}\right]$ thymidine $(1$ $\mu \mathrm{Ci} /$ well; sp act $5 \mathrm{Ci} / \mathrm{mmol}$; Amersham International, Amersham, England). $16 \mathrm{~h}$ later the cells were harvested with a multiple cell harvester (Titertek, Elfab Oy, Finland), and thymidine incorporation was measured in a liquid scintillation counter. The results were expressed as cpm $\left[{ }^{3} \mathrm{H}\right]$ thymidine uptake (mean of triplicate cultures $\pm \mathrm{SD}$ ).

Proliferation assay (AChR-reactive, selected $T$ cells). AChR-reactive $T$ cells were cultured and labeled as described above for unselected
PBMC, except that the concentration of the responding $T$ cells was only $1 \times 10^{4}$ cells $/ 0.2 \mathrm{ml} / \mathrm{microwell}$, and that $2 \times 10^{5} \mathrm{HLA}$-matched (patient 2) or autologous (patient 1) mitomycin C-treated PBMC were added into each well as antigen-presenting cells.

\section{Results}

Antigen reactivity of unselected $P B M C$. Table I shows the reactivity of unselected peripheral blood cells in the absence of antigen or with different antigens that were used when the primary cultures for the selection of AChR-specific $\mathrm{T}$ cells were started in 1983 (patient 1) and in 1987 (patient 2). Reactivity with tuberculin was detectable in patient 1 , and with tetanus toxoid in patient 2 . However, there was no significant reactivity with solubilized Torpedo AChR at the optimal stimulating concentration established in previous experiments $(5$ $\mu \mathrm{g} / \mathrm{ml} ; \sim 20-25 \mathrm{nM})(4,8)$. Reactivity with the synthetic peptides P1-P3 (cf. Fig. 1), which was tested in patient 2, was also within or slightly below the background range.

Antigen reactivity of $A C h R$-specific $T$ cells. Fig. 2 shows the $A C h R$ response of the $C D 3, C D 4-p o s i t i v e ~ T$ cell lines that were derived from these PBMC by in vitro selection with solubilized Torpedo AChR (see Methods section). In this experiment the number of responding cells per culture well was only $1 \times 10^{4}$ compared with $2 \times 10^{5}$ in the case of unselected PBMC. In patient 1 (HLA-DR1,4), the AChR-reactive selected T cells were stimulated significantly in the presence of peptides P2 and P3 (Fig. 2, top). After subtracting the background counts, peptides P2 and P3 evoked roughly $30 \%$ of the response obtained with solubilized native Torpedo AChR. The selected helper $T$ cells from patient 2 (HLA-DR3,8) did not at all recog-

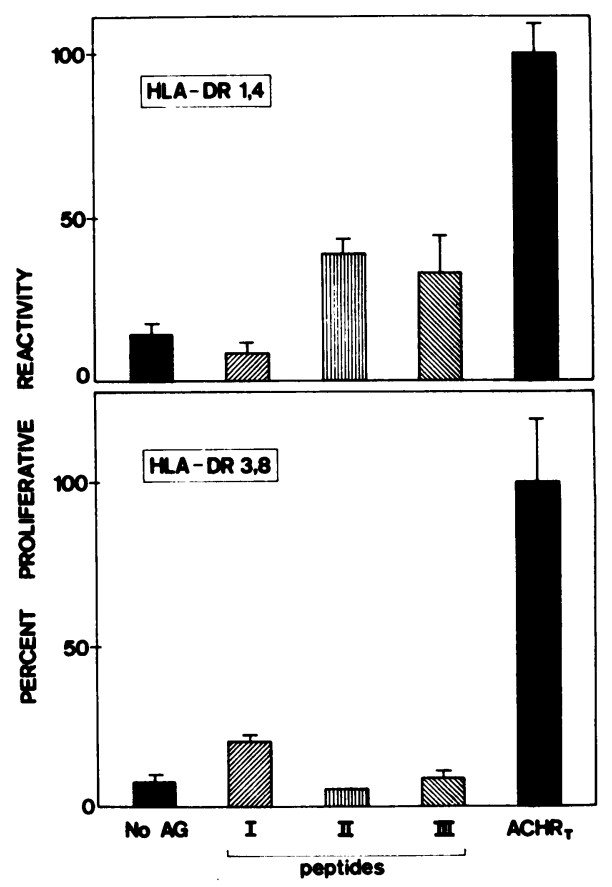

Figure 2. Peptide reactivity of selected, AChR-specific T cells. Top: patient 1 (HLA-DR 1,4); bottom: patient 2 (HLA-DR3,8). Results are expressed as percent of the proliferative response $\left(\left[{ }^{3} \mathrm{H}\right]\right.$ thymidine uptake; mean of triplicate cultures $\pm \mathrm{SD}$ ) in the presence of $5 \mu \mathrm{g} / \mathrm{ml} \mathrm{sol-}$ ubilized Torpedo AChR $\left(\mathrm{AChR}_{\mathrm{T}}\right)$. No $A G$ (antigen): background proliferation in the absence of antigen. Absolute counts (100\%) were $5,260 \pm 670$ (patient 1) and 12,980 11,760 (patient 2). 
Table I. Antigen Reactivity of Unselected PBMC*

\begin{tabular}{lcc}
\hline \multicolumn{1}{c}{ Antigen } & Patient 1 & Patient 2 \\
\hline No antigen & $3,033 \pm 380$ & $1,172 \pm 408$ \\
PPD & $6,085 \pm 1,217$ & $1,168 \pm 201$ \\
Tetanus toxoid & NT & $6,231 \pm 690$ \\
PHA & $67,623 \pm 3,245$ & $32,928 \pm 3,580$ \\
Native Torpedo AChR & $3,810 \pm 953$ & $1,309 \pm 445$ \\
Peptide 1 & NT & $1,219 \pm 304$ \\
Peptide 2 & NT & $1,125 \pm 467$ \\
Peptide 3 & NT & $747 \pm 529$ \\
& & \\
\hline
\end{tabular}

NT, not tested.

* cpm $\left[{ }^{3} \mathrm{H}\right]$ thymidine uptake (mean of triplicate cultures $\pm \mathrm{SD}$ ).

nize peptides P2 and P3 (Fig. 2, bottom). A small but significant response was detected against peptide $P 1(\sim 10 \%$ of the response induced with native solubilized Torpedo $A C h R)$. The optimal stimulating concentration was $\sim 1 \mu \mathrm{g} / \mathrm{ml}(0.5 \mu \mathrm{M})$ for all three peptides. As can be seen from Table I and by comparing the upper and lower panels in Fig. 2, the peptides had no significant unspecific stimulatory or inhibitory effects at this concentration.

\section{Discussion}

Three peptides of $\sim 2,000 \mathrm{~mol}$ wt induced between 10 and $30 \%$ of the proliferative response evoked in the same pluriclonal $\mathrm{T}$ cells with intact $\mathrm{AChR}$, which has a molecular weight of $\sim 270,000(2,3)$. This suggests that the $T$ helper cells recognized a limited number of AChR epitopes. These findings also indicate that other $\mathrm{T}$ cell-stimulating epitopes must exist on the AChR molecule. Since most of the determinants recognized by autoimmune $T$ helper cells are located on the alpha subunit (8), the additional, as yet undefined, epitopes are positioned between the end of peptide P3 and the carboxy-terminal end of the alpha subunit (Fig. 1). This conclusion is supported by recent findings of other groups who have evidence for at least two additional distinct $T$ cell-stimulating epitopes that are carboxy-terminal to sequence 1-34 (Lawrence Steinman, personal communication, and reference 15,16$)$. It is likely that several different $\mathrm{T}$ cell clones, each recognizing different sites on the alpha subunit, participate in the autoimmune reaction against $\mathrm{AChR}$. This would argue against the possibility that MG is initiated by one single "forbidden clone" (17) of autosensitized $T$ helper cells.

The autoreactive $T$ cells studied here reacted to peptides which represent one of the sections of the alpha subunit pre- dicted to be particularly immunogenic for $\mathrm{T}$ cells (see Methods). The sequences of these peptides display a high degree of periodicity in hydrophobic residues, and have a propensity to form an amphipathic alpha helix. Such structure could be favored and stabilized by the amphipathic environment at the surface of the antigen-presenting cell. This does not require that the native secondary structure of the intact protein is also alpha-helical $(12,13)$. Most of the known helper $T$ cell epitopes show a propensity to form amphipathic helices (reviewed in references 18, 19). Our present results indicate that this also applies to a set of epitopes on the $\mathrm{NH}_{2}$-terminal alpha subunit of the AChR molecule.

Since our $\mathrm{T}$ cell lines were selected in vitro with Torpedo $\mathrm{AChR}$, they do not necessarily represent the in vivo repertoire. However, there is evidence that the extent of cross-reactivity between Torpedo and human AChR is high at the level of unselected T cells (reference 8 and unpublished observations). This would indicate that Torpedo $\mathrm{AChR}$ is a reasonable substitute for human AChR in the selection of autoreactive human T cells. Table II compares the sequence of the aminoterminal 34 amino acids of the human and Torpedo AChR alpha chain, i.e., the segment that is represented by the three peptides used to stimulate the $T$ cell lines. The amino acid substitutions, some of which are highly conservative, do not alter the amphipathic character of this segment. It has the highest amphipathic score (13) of all amphipathic sequences both in the human and Torpedo AChR alpha chain (the calculated amphipathic score is $\mathbf{5 5 . 4}$ for the human and 56.1 for the Torpedo $\mathrm{NH}_{2}$-terminal segment).

It is tempting to speculate that the $\mathrm{T}$ cell epitopes are represented by the sequences that are shared between the human and Torpedo AChR. However, one must take into consideration that it is unknown how individual amino acid substitutions affect the integrity of either the $\mathrm{T}$ cell epitope or the "agretope" (the site interacting with the restricting histocompatibility molecule (20). The epitope and the agretope may not be laterally separable and may be composed of interspersed amino acid residues $(18,19,21)$. Moreover, the agretope and the $T$ cell epitope may differ in their sensitivity to amino acid substitutions (22). To identify these sites it will be necessary to develop clones of $\mathrm{AChR}$-specific $\mathrm{T}$ cells and to systematically test their reactivity against panels of substituted peptides.

The extent of clonal diversity of $\mathrm{T}$ cell autoimmune reactions is a key issue with regard to possible clinical applications for immunotherapy. Our data indicate that (a) the anti-AChR $T$ cell autoimmune response, although limited in its clonal diversity, is nevertheless heterogeneous in individual patients (intraindividual heterogeneity), and that $(b)$ it varies between different patients (interindividual variability). With regard to intraindividual heterogeneity of the $T$ cell autoimmune re-

Table II. Comparison of the Amino-Terminal Sequence of the Human and Torpedo californica AChR Alpha Subunit

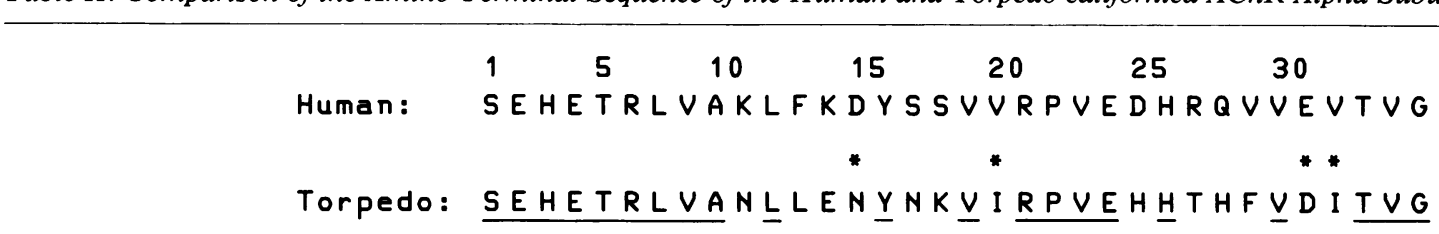

The sequences (taken from reference 24) are shown by the one-letter amino acid notation. Shared residues are underlined. Conservative substitutions are marked with an asterisk. 
sponse, recent results in experimental autoallergic encephalomyelitis are relevant. Zamvil et al. (23) showed that only a very limited repertoire of autoaggressive $T$ cells induce experimental autoallergic encephalomyelitis, and that only a subset of the $\mathrm{T}$ cells that recognize the autoantigen, myelin basic protein, is encephalitogenic. By analogy, it is possible that not all of the helper $\mathrm{T}$ cells that recognize $\mathrm{AChR}$ in a given patient are relevant for the disease because they do not help in the production of myasthenogenic anti-AChR autoantibodies. Therefore, even in a heterogeneous population of autoimmune $T$ cells, it may be possible to define a small number of $\mathrm{T}$ cell clones against which specific therapy could be targeted (9).

Interindividual variability of the autoimmune response could be partially explained by the fact that $T$ helper cells recognize antigen in association with class II histocompatibility antigens (MHC restriction; reviewed in reference 20). It is well established that these "restricting" histocompatibility molecules influence $T$ cell responsiveness, and that the immunodominance of particular antigen epitopes depends strongly on the MHC antigens used as restriction elements (reviewed in references 18, 20). Further analyses in this system may help to better define the suspected relationship between HLA class II molecules expressed by individual patients and the antigenic fine specificity of their autoimmune $\mathrm{T}$ cells.

\section{Acknowledgments}

We are grateful to our patients for their cooperation; to Drs. J. Cornette, H. Margalit, C. DeLisi, and J. A. Berzofsky for analyzing the $A C h R$ alpha subunit sequence for candidate $T$ cell recognition sites; to Dr. J. Bertrams for determining the HLA-types; and to Ms. A. Fahsbender for excellent technical assistance.

This study was supported by a grant of the Muscular Dystrophy Association of America and US-NINCDS grant NS-28199 (to B. M. Conti-Tronconi), and by the Deutsche Forschungsgemeinschaft (SFB 200, B5). R. Hohlfeld is a Heisenberg Fellow of the Deutsche Forschungsgemeinschaft.

\section{References}

1. Engel, A. G. 1984. Myasthenia gravis and myasthenic syndromes. Ann. Neurol. 16:519-534.

2. McCarthy, M., J. P. Earnest, E. I. Young, S. Choe, and R. M. Stroud. 1986. The molecular neurobiology of the acetylcholine receptor. Annu. Rev. Neurosci. 9:383-414.

3. Conti-Tronconi, B. M., and M. A. Raftery. 1982. The nicotinic cholinergic receptor: correlation of molecular structure with functional properties. Annu. Rev. Biochem. 51:491-530.

4. Tzartos, S. J., M. E. Seybold, and J. Lindstrom. 1982. Specificities of antibodies to acetylcholine receptors in sera from myasthenia gravis patients measured by monoclonal antibodies. Proc. Natl. Acad. Sci. USA. 79:188-192.

5. Killen, J. A., S. M. Hochschwender, and J. Lindstrom. 1985. The main immunogenic region of acetylcholine receptors does not provoke the formation of antibodies of a predominant idiotype. J. Neuroimmunol. 9:229-241.

6. Hohlfeld, R., K. V. Toyka, K. Heininger, H. Grosse-Wilde, and I. Kalies. 1984. Autoimmune human helper T-lymphocytes specific for acetylcholine receptor. Nature (Lond.). 310:244-246.

7. Hohlfeld, R., I. Kalies, B. Kohleisen, K. Heininger, B. M. Conti-Tronconi, and K. V. Toyka. 1986. Myasthenia gravis: stimula- tion of antireceptor autoantibodies by autoreactive $\mathrm{T}$ cell lines. Neurol$o g y$ (N.Y.). 36:618-621.

8. Hohlfeld, R., K. V. Toyka, S. J. Tzartos, W. Carson, and B. M. Conti-Tronconi. 1987. Human T-helper lymphocytes in myasthenia gravis recognize the nicotinic receptor alpha subunit. Proc. Natl. Acad. Sci. USA. 84:5379-5383.

9. Hohlfeld, R., and K. V. Toyka. 1985. Strategies for the modulation of neuroimmunological disease at the level of autoreactive $\mathrm{T}$ lymphocytes. J. Neuroimmunol. 9:193-204.

10. Besinger, U. A., K. V. Toyka, M. Hoemberg, K. Heininger, R. Hohlfeld, and A. Fateh-Moghadam. 1983. Myasthenia gravis: longterm correlation of binding and bungarotoxin blocking antibodies against acetylcholine receptors with changes in disease severity. Neurology (N.Y.). 33:1316-1321.

11. Houghten, R. A. 1985. General method for the rapid solidphase synthesis of large numbers of peptides: specificity of antigen-antibody interaction at the level of individual amino acids. Proc. Natl. Acad. Sci. USA. 82:5131-5135.

12. DeLisi, C., and J. A. Berzofsky. 1985. T-cell antigenic sites tend to be amphipathic structures. Proc. Natl. Acad. Sci. USA. 82:70487052.

13. Margalit, H., J. Spouge, J. Cornette, K. Cease, C. DeLisi, and J. A. Berzofsky. 1987. Prediction of immunodominant helper T cell antigenic sites from the primary sequence. J. Immunol. 138:22132229.

14. Heinrikson, R. L., and S. C. Meredith. 1984. Amino acid analysis by reverse-phase high-performance liquid chromatography: precolumn derivatization with phenylisothiocyanate. Anal. Biochem. 136:65-74.

15. Harcourt, G., N. Sommer, J. Rothbard, D. Beeson, N. Willcox, and J. Newsom-Davis. 1987. Blood and thymic lymphocyte responses to peptide sequences of the acetylcholine receptor in myasthenia gravis. J. Neuroimmunol. 16:70. (Abstr.)

16. Melms, A., T. Kirchner, T. Barkas, S. Tzartos, B. Schalke, H. K. Mueller-Hermelink, and H. Wekerle. 1987. Intrathymic pathogenesis of Myasthenia gravis: AChR-specific T-lymphocytes and AChR expression in the myasthenic thymus. J. Neuroimmunol. 16:122. (Abstr.)

17. Burnet, F. M. 1959. The Clonal Selection Theory of Acquired Immunity. Vanderbilt University Press, Nashville, TN. 1-208.

18. Livingstone, A. M., and C. G. Fathman. 1987. The structure of T cell epitopes. Annu. Rev. Immunol. 5:477-501.

19. Berzofsky, J. A., K. B. Cease, J. L. Cornette, J. L. Spouge, H. Margalit, I. J. Berkower, M. F. Good, L. H. Miller, and C. DeLisi. 1987. Protein antigenic structures recognized by T cells: potential applications to vaccine design. Immunol. Rev. 98:9-52.

20. Schwartz, R. H. 1985. T-lymphocyte recognition of antigen in association with gene products of the major histocompatibility complex. Annu. Rev. Immunol. 3:237-261.

21. Allen, P. M., G. R. Matsueda, R. J. Evans, J. B. Dunbar, G. R. Marshall, and E. R. Unanue. 1987. Identification of the T-cell and Ia contact residues of a T-cell antigenic epitope. Nature (Lond.). 327:713-715.

22. Sette, A., S. Buus, S. Colon, J. A. Smith, C. Miles, and H. M. Grey. 1987. Structural characteristics of an antigen required for its interaction with Ia and recognition by $\mathrm{T}$ cells. Nature (Lond.). 328:395-399.

23. Zamvil, S. S., D. J. Mitchell, A. C. Moore, K. Kitamura, L. Steinman, and J. B. Rothbard. 1986. T-cell epitope of the autoantigen myelin basic protein that induces encephalomyelitis. Nature (Lond.). 324:258-260.

24. Noda, M., Y. Furutani, H. Takahashi, M. Toyosato, T. Tanabe, S. Shimizu, S. Kikyotani, T. Kayano, T. Hirose, S. Inayama, and S. Numa. 1983. Cloning and sequence analysis of calf cDNA and human genomic DNA encoding alpha-subunit precursor of muscle acetylcholine receptor. Nature (Lond.). 305:818-823. 